

\section{TABLE OF CONTENTS}

Non-technical summary. . . . . . . . . . . . . . . . . . . . . . . . . . . 3

Abstract . . . . . . . . . . . . . . . . . . . . . . . . . 3

Résumé non technique . . . . . . . . . . . . . . . . . . . . . . . . . . . 4

Résumé court . . . . . . . . . . . . . . . . . . . . . . . . . . . 5

1. Introduction . . . . . . . . . . . . . . . . . . . . . . . . . . . . . 6

2. The model. . . . . . . . . . . . . . . . . . . . . . . . . . . . 8

2.1. Households . . . . . . . . . . . . . . . . . . . . . . . . . . . . 8

2.2. Firms . . . . . . . . . . . . . . . . . . . . . . 10

2.3. Government . . . . . . . . . . . . . . . . . . . . . . . 10

2.4. Markets, trade and the current account . . . . . . . . . . . . . . . . . . 11

3. Long term impact of taxation in an economy with capital . . . . . . . . . . . . 12

3.1. The steady state. . . . . . . . . . . . . . . . . . . . . . . . . . . 12

3.2. Calibration. . . . . . . . . . . . . . . . . . . . . . . 14

4. The short term impact of national tax reform . . . . . . . . . . . . . . . . 15

4.1. Transitory effect of fiscal shocks: an application to Germany . . . . . . . . . 15

4.2. The political economy of national tax reforms in a monetary union . . . . . . . 15

5. Conclusion . . . . . . . . . . . . . . . . . . . . . . . . . . . . 17

Bibliography . . . . . . . . . . . . . . . . . . . . . . . . . 18

Appendix . . . . . . . . . . . . . . . . . . . . . . . . . . . . . . . . 19

A. Price setting . . . . . . . . . . . . . . . . . . . . . . . . . . 19

B. Trade model calibration. . . . . . . . . . . . . . . . . . . . . . . . 20

List of working papers released by CEPII . . . . . . . . . . . . . . . . . . . . 24 


\title{
TAX REFORM AND COORDINATION IN A CURRENCY UNION
}

Benjamin Carton

\section{NON-TECHNICAL SUMMARY}

Facing the ongoing ageing process, European countries will have to address a significant increase in the cost of their social system. In addition, the large public debt inherited from the 2008-2009 economic crisis adds to the demographic burden. Cuts in other public expenditures are unlikely to finance the whole burden, a share of it will have to be finance through tax increase. Given the size of the adjustment, tax increase will rely on labor and consumption taxation. Besides this concern, some countries belonging to the euro area have considered some form of fiscal devaluation, or even already implemented it, through a shift from labor tax to consumption tax.

We propose a two-country DSGE model to analyze at the same time both short-term and long-term impact of a modification of consumption and labor taxation rate in one country in a currency union. The model embodies the fact that firms differ in their pricing behavior after a VAT tax increase: some of them pass it through consumption price immediately; others smooth the price increase over many quarters. The model shows that the short term impact on inflation and the output-gap is different according to the modified tax (consumption, workers' contributions, firms' contributions) and the schedule of preannouncement. Due to the common monetary policy, national tax policies have large spill-overs on the rest of the currency union. Furthermore, a fiscal devaluation is different from a nominal devaluation due to the common monetary policy. We then calibrate the model for Germany and the rest of the euro area in order to estimate the macroeconomic impact on Germany and the rest of the euro area of the policy effectively implemented on January 2007.

\begin{abstract}
We propose a two-country DSGE model to analyze short-term and long-term impact of a modification of consumption and labor tax rate in one country in a currency union. The model embodies the fact that firms differ in their pricing behavior after a VAT tax increase. Due to the common monetary policy, national tax policies have large spill-overs on the rest of the currency union. Furthermore, a fiscal devaluation is different from a nominal devaluation due to the common monetary policy.
\end{abstract}

JEL Classification: F56, C12.

Keywords: $\quad$ Fiscal Policy, Monetary Policy, DSGE, Value added tax, Monetary Union 


\section{RÉFORMES FISCALES ET COORDINATION EN UNION MONÉTAIRE}

Benjamin Carton

\section{RÉSUME NON TECHNIQUE}

En raison du vieillissement de la population, les pays européens devront faire face dans les années à venir à une forte augmentation des prestations sociales liées aux dépenses de santé et au financement des systèmes de retraite. À cette augmentation des dépenses sociales s'ajoute le niveau élevé de la dette publique atteint à la suite de la crise économique de 2008-2009. Or l'essentiel de la fiscalité repose en Europe sur les salaires ou la consommation et la hausse à venir des prélèvements ne pourra se passer ni de l'une ni de l'autre de ces deux bases fiscales. Mais, faire reposer cette hausse des prélèvements davantage sur l'un ou l'autre des ces deux piliers n'est pas neutre et une abondante littérature a étudié l'incidence fiscale des réformes du financement des prestations sociales. Nous empruntons une autre voie consistant à évaluer simultanément les effets à court terme et long terme des modifications de taux de taxation, en particulier ceux lié aux rigidités nominales et à la monnaie unique.

Nous évaluons l'effet d'une substitution, dans un pays de la zone euro, de la taxation du facteur travail par la taxation de la consommation (appelée aussi TVA sociale ou TVA compétitivité) tant dans le pays qui met en œuvre la réforme fiscale que dans le reste de la zone monétaire. Nous appuyons notre analyse sur un modèle stochastique dynamique d'équilibre général (DSGE) contenant des rigidités réelles et nominales. Les articles ayant étudié la question montrent qu'une telle substitution est bénéfique lorsque l'assiette de la consommation (les dépenses de consommation des ménages) est supérieure à l'assiette des cotisations sociales (la rémunération du travail) : le pouvoir d'achat du travail, qui dépend des deux taux de taxation, peut augmenter sans que le total des recettes fiscales ne diminue. Nous soulignons que cette « condition d'assiette » est incomplète. D'une part, elle néglige les effets de redistribution de la substitution entre les deux taxes qui affectent le pouvoir d'achat des transferts aux ménages (retraités, chômeurs, les plus pauvres). Dès lors, dans la comparaison des assiettes de chacune des taxes, il faut ôter de l'assiette de la TVA l'ensemble de la consommation financée par ces transferts. D'autre part, il y a un lien entre le taux d'intérêt à long terme et la structure de la taxation. La TVA taxe les ménages tout au long de leur vie tandis que les taxes sur le travail concentrent les prélèvements sur la seule vie active. Une TVA sociale devrait donc accroître l'épargne des ménages, diminuer le taux d'intérêt et augmenter le stock de capital dans l'économie. Ces arguments soulignent combien il est difficile d'estimer le bénéfice de telles réformes fiscales tant le nombre de canaux par lesquels les effets transitent sont nombreux.

En restant dans un cadre simple où le taux d'intérêt à long terme ne dépend pas de la structure de la taxation, le modèle DSGE à deux zones calibré sur l'Allemagne et le reste de la zone euro montre que 
l'impact à court terme sur l'inflation et le taux d'intérêt dépend de la taxe modifiée (TVA, cotisations employeurs ou cotisations employés) et du calendrier de la mesure (annonce préalable de la politique). La politique effectivement mise en œuvre en Allemagne en janvier 2007 (hausse de trois points de la TVA et baisse de 0,5 point des cotisations sociales employés et employeurs) a conduit à un hausse de la consommation et de l'activité à court terme en Allemagne et à une baisse dans le reste de la zone euro. De façon plus générale, les externalités des différentes réformes fiscales envisagées (taxes indirectes) ont toutes la même ampleur sauf lorsque le pays change son taux de TVA et que la transmission aux prix à la consommation est lent, ou lorsque le changement de TVA est annoncé à l'avance. Dans ces deux cas particuliers, un écart de taux d'inflation apparaît de façon durable entre le pays qui met en place la réforme et le reste de la zone monétaire, ce qui, en raison de la politique monétaire commune, se traduit automatiquement par un écart de taux d'intérêt réel. Un report de la taxation du travail vers la consommation (TVA sociale ou TVA compétitivité) dans un pays induit un coût relativement important pour le reste de la zone monétaire.

\section{RÉSUMÉ COURT}

Nous proposons un modèle DSGE à deux pays pour analyser l'impact à court et à long terme d'une modification de la TVA et des cotisations sociales dans un pays de l'union monétaire. Le modèle prend en compte le fait que les entreprises diffèrent dans leur comportement prix après une hausse de la TVA. En raison de la politique monétaire commune, les politiques fiscales nationales ont des externalités sur le reste de l'union monétaire. En particulier, les effets d'une dévaluation fiscale sont différents de ceux d'une dévaluation nominale.

\section{Classification JEL: F56, C12.}

Mots clés : $\quad$ Politiques macroéconomiques, DSGE, TVA, Union monétaire. 


\section{TAX REFORM AND CoORdination IN A CURRENCY UNION}

Benjamin Carton*

\section{INTRODUCTION}

Most of the tax burden in Europe is shared between labor (social contributions) and consumption (VAT); the share of the latter has been growing over the last 25 years (see Figure 1). The consequences of the financial and economic crisis on public finance and the ongoing aging process will require further tax increases in the near future.

Figure 1 - Standard VAT rates in euro area

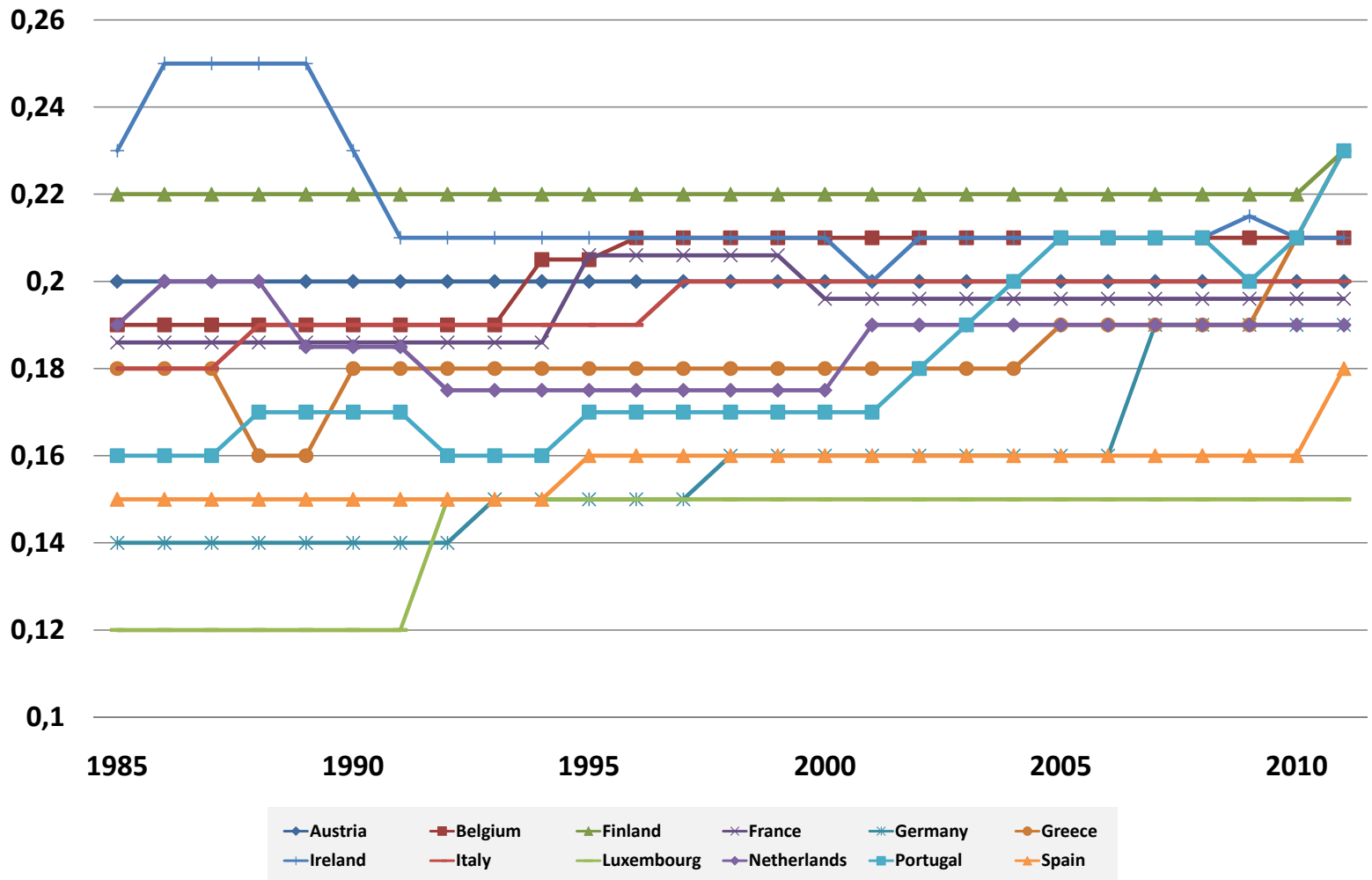

There is a large literature dealing with the analysis of tax policies from the micro perspective

*CEPII (benjamin.carton@cepii.fr). I am grateful to Guido Ascari, Michel Juillard, Lorenza Rossi, Thibault Guyon, Martine Carré and the participants of the EUROFRAME conference in June 2008 for helpful comments. The usual disclaimer applies. 
(tax incidence), emphasizing their impact on resource allocation and their redistributive effects ${ }^{1}$ and assessing optimal taxation ${ }^{2}$. An other approach looks at how a change of the fiscal stance affects the aggregate demand and supply, prices and output ${ }^{3}$. There is now a growing 'policy oriented' literature aiming to close the gap between the two approaches. It is traditionally based on dynamic general equilibrium models including real and nominal rigidities to reproduce short run stylized facts. A recent contribution is Coenen et al. (2007) who focus on Euro Areawide consumption and labor tax reduction using the New Area-Wide Model (NAWM). In a similar vein, Roeger \& in't Veld (2006) estimate the impact of shifting taxation from labor to consumption. Product and labor market reforms that may increase competition or decrease the NAIRU have been also analyzed with the same objective of closing the gap between short term and long term impacts. Adjemian et al. (2009) illustrate a robustness analysis of dynamic response to an anticipated VAT increase in a medium-size DSGE model à la Smets \& Wouters (2003). Fève et al. (2009) evaluate the welfare gain of switching from a labor tax to consumption tax in a closed-economy, flexible-price DGE model with matching frictions in the labor market. Coupet \& Renne (2008) investigate the impact of the same tax reforms in a small open-economy framework.

This paper proposes a medium-size DSGE model to evaluate the short and long-term consequences of a national consumption-based and compensation-based tax reforms in a currency union, both for the country implementing the policy and the rest of the union. In the first part, we discuss how our particular framework is able to take into account the three main dimensions of a tax reform in the long run: (a) the tax wedge and the labor supply, (b) the redistributive effects, (c) the government budget constraint. The representative agent hypothesis and the existence of lump-sum taxes make the second and the third point trivial. However, one can discuss them relevantly, if not properly. In the second part, we illustrate the main conclusions of the dynamic model (macroeconomic impact and welfare analysis) with a calibration on Germany and the rest of the euro area.

National tax policies may spill over to the rest of the currency union through many channels. In the long run, the modification of tax rates shifts the equilibrium term-of-trade. Absent price adjustment in the short run, the margin of foreign IT firms producing for the domestic market is too low when VAT increases, the relative price between domestic and foreign firms varies and thus reallocates demand from a region to the other, the common monetary policy will take into account the average inflation rate of the currency union and then setting interest rates to inefficient level for the foreign region.

Section 2 presents the two-country model with price rigidities for including-tax and excludingtax prices, Section 3 investigates the long-run effect of shifting taxation from labor to consump-

\footnotetext{
${ }^{1}$ for instance, Boeters et al. (2006) evaluate the long term impact of the 2007 German tax reform and Feenberg et al. (1997) address the distributional effect of shifting to a consumption tax.

${ }^{2}$ Chamley (1986) on capital taxation.

${ }^{3}$ Henry et al. (2004) make a comparison between different estimations with macro-models.
} 
tion and Section 4 evaluates the short run effect of shifting taxation in one country in a currency union with a calibration for the German reform in 2007.

\section{THE MODEL}

The currency union is split into two regions: one country, which implements the tax policy, and the rest of the euro area (REA). For sake of simplicity, we ignore the rest of the world. The two regions share the same structure and differ only by their size. They also share the same nominal interest rate but labor and capital markets are segmented. A one-period risk-free bond in euro is the only internationally-traded financial asset (we do not assume perfect international risk sharing).

To take into account the dynamic of aggregate consumption price following a consumption tax increase, we introduce two types of firms: IT (including tax price setters) and ET (excluding tax price setters). The two types of firms are perfectly similar except in one dimension: the way they set their price.

- IT firms set a price that includes the consumption tax. Following a consumption tax increase, the price consumers face stay constant whereas sales income is reduced by the higher tax rate.

- ET firms set a price that does not include the consumption tax. Following a consumption tax increase, the price consumers face surge whereas sales income is maintained.

Firms produce both for the domestic and the foreign market. Goods are not perfect substitutes and preferences exhibit home bias. Each region is populated by infinite planning horizon households, ET firms, IT firms producing differentiated goods with both capital and labor, a fiscal authority that levies taxes (on consumption and labor) and purchases goods and a monetary authority that sets the short term nominal interest rate. We assume that monetary authorities follow a simple rule based on core inflation (a relevant average of IT-inflation and ET-inflation) and wage-inflation.

\subsection{Households}

Utility and the budget constraint In each region, infinitely-lived households $(j \in[0,1])$ maximize the following utility function, that exhibits external (catch-up with the Jones) consumption habits, that depends on consumption $\left(C_{t}\right)$ and labor supply $\left(N_{t}\right)$

$$
\mathbf{E}_{0} \sum_{t=0}^{\infty} \beta\left[\frac{\left(C_{t}(j)-b \bar{C}_{t}\right)^{1-\sigma}}{1-\sigma}-\frac{N_{t}(j)^{1+\varphi}}{1+\varphi}\right]
$$

where $\bar{C}_{t}$ is equal to aggregate consumption at period $t-1$ and parameters $0<\beta<1,0<b<$ $1, \sigma>0$ and $\varphi$ measure the discount factor, habit persistence, the inverse of inter-temporal elasticity of substitution and the Frisch-elasticity of labor supply. 
The disposable income of households is made of

- net of tax labor income $\tau_{t}^{h} W_{t}(j) N_{t}(j)$, where $1-\tau_{t}^{h}$ is the tax rate and $W_{t}$ the negotiated wage;

- capital income $r_{t} K_{t-1}(j)$, where $r k_{t}$ is the rental price of capital and $K_{t-1}$ the capital inherited from the previous period;

- profits $\Pi_{t}$;

- the revenue from nominal bond holding $B_{t}(j)$;

- net of direct taxes T.

They consume $C_{t}$, invest $I_{t}$, and trade domestic state-contingent securities $B_{t+1} \cdot{ }^{4}$ As investment goods are not taxed by consumption tax, one has to distinguish consumption price $P_{c, t}$ and investment price $P_{k, t}$. $\mathscr{F}_{t}^{t+1}$ denotes the price at $t$ of a contingent security that delivers one unit of the numeraire at $t+1$ when the relevant state of nature is realized. The budget constraint is given by

$$
P_{c, t} C_{t}(j)+P_{k, t} I_{t}(j)+\mathbf{E}_{t}\left\{\mathscr{F}_{t}^{t+1} B_{t+1}(j)\right\}=\tau_{t}^{h} W_{t}(j) N_{t}(j)-\mathrm{T}_{t}+r k_{t} K_{t-1}(j)+\Pi_{t}+B_{t}(j)
$$

Perfect risk sharing and the Euler equation Thanks to the complete set of contingent claims, households are able to insure against idiosyncratic shocks. Assuming a symmetric initial condition, households will all share the same level of consumption whatever the state of nature. This result comes from the first order condition on claim holding:

$$
\mathscr{F}_{t}^{t+1}=\beta \frac{P_{c, t+1}\left(C_{t+1}(j)-b \bar{C}_{t+1}\right)^{-\sigma}}{P_{c, t}\left(C_{t}(j)-b \bar{C}_{t}\right)^{-\sigma}} .
$$

Let $R$ the (gross) nominal interest rate (common to the two regions), the Euler equation is given by

$$
\mathbf{E}_{t}\left\{\mathscr{F}_{t}^{t+1} R_{t}\right\}=1
$$

Investment To introduce real rigidities on investment, capital accumulation suffers adjustment costs when investment rate goes far away the stationary or the previous period investment rate

$$
K_{t}(j)=\Phi\left(\frac{I_{t}(j)}{K_{t-1}(j)}\right) K_{t-1}(j)
$$

\footnotetext{
${ }^{4}$ State-contingent securities are not traded internationally (there is no international risk-sharing), but nominal risk-free bonds are. State-contingent securities are introduced in order to properly define the firm objective and to insure households against the risk of not being able to re-optimize its wage the next period in the Calvo-setting wage stickiness.
} 
where $\Phi(x)=1-\delta+x-\frac{\phi_{I h 1}}{2}(x-\delta)^{2}-\frac{\phi_{I h 2}}{2}\left(x-\frac{I(-1)}{K(-2)}\right)^{2}$. Let $q$ the nominal Tobin's marginal $Q$. Household's optimal investment implies the following first order condition

$$
P_{k, t}=\Phi^{\prime}\left(\frac{I_{t}}{K_{t-1}}\right) \mathbf{E}\left\{\mathscr{F}_{t}^{t+1}\left[P_{k, t+1}\left(\frac{\Phi_{t+1}}{\Phi_{t+1}^{\prime}}\left(\frac{I_{t+1}}{K_{t}}\right)-\frac{I_{t+1}}{K_{t}}\right)+r k_{t+1}\right]\right\} .
$$

Labor market and wage setting Labors of different households are imperfect substitute, with an elasticity $\varepsilon_{w}$. Household $j$ set the wage $W_{t}(j)$. The aggregate wage $W_{t}$, and labor demand $N_{t}(j)$ addressed to household $j$ are given by

$$
W_{t}=\left(\int_{0}^{1} W_{t}(j)^{1-\varepsilon_{w}} d j\right)^{\frac{1}{1-\varepsilon_{p}}} \quad N_{t}(j)=\left(\frac{W_{t}(j)}{W_{t}}\right)^{-\varepsilon_{w}} N_{t}
$$

Calvo-style wage setting produces nominal rigidities and $\theta_{w}$ denotes the probability to not be able to reseting its wage a given period.

\subsection{Firms}

In each country, firms produce with a standard Coob-Douglas technology that requires labor and capital. However, they differ in the way they set prices. Some firms (a share $\eta$ ) set an excluding tax price both for the domestic and the foreign market, they are denoted ET-firms. Others set an including-tax price for the domestic market or the foreign market. We distinguish the two types of IT firms because the level of consumption tax is specific to the consumer country, not the producer country. Price are sticky à la Calvo, but the relevant sticky-price is the excluding-tax (producer) price for ET firms or the including-tax (consumer) price for IT firms. In each country there are three different price behaviors:

ET Firms set a sticky excluding-tax price both for the domestic market and export market. The aggregate price is $P_{\mathrm{ET}}$;

IT, $d$ Firms set a sticky including-tax price for the domestic market (the domestic VAT rate applies). The aggregate price is $P_{\mathrm{IT}, d}$;

IT, $x$ Firms set a sticky including-tax price for the export market (the foreign VAT rate applies). The aggregate price is $P_{\mathrm{IT}, x}$.

The price setting decisions are given in Appendix A.

\subsection{Government}

In each region, the government raises tax (consumption tax, labor tax, direct lump-sum tax on households) and has public expenditures. ${ }^{5}$ The budget constraint of the government writes

$$
\left(\tau_{t}^{f}-\tau_{t}^{h}\right) W_{t} N_{t}+\frac{\tau_{t}^{c}-1}{\tau_{t}^{c}} P_{c, t} C_{t}+\mathrm{T}_{t}=P_{g, t} G_{t},
$$

\footnotetext{
${ }^{5}$ We assume no debt as Ricardian equivalence holds with the direct lump-sum tax.
} 
where $\tau^{f}$ is the gross tax rate on labor payed by firms, $\tau^{c}$ the gross consumption tax rate, $G_{t}$ the government expenditure in volume and $P_{g, t}$ the government expenditure deflator.

\subsection{Markets, trade and the current account}

Consumption, investment and public expenditures The household of Home has the following consumption bundle

$$
\begin{aligned}
& C=\left([(1-\gamma) \eta]^{\frac{1}{\varepsilon}} C_{\mathrm{ET}, d^{\frac{\varepsilon-1}{\varepsilon}}}\right. {[(1-\gamma)(1-\eta)]^{\frac{1}{\varepsilon}} C_{\mathrm{IT}, d^{\frac{\varepsilon-1}{\varepsilon}}} } \\
&\left.+[\gamma \eta]^{\frac{1}{\varepsilon}} C_{\mathrm{ET}, m}{ }^{\frac{\varepsilon-1}{\varepsilon}}+[\gamma(1-\eta)]^{\frac{1}{\varepsilon}} C_{\mathrm{IT}, m}^{\frac{\varepsilon-1}{\varepsilon}}\right)^{\frac{\varepsilon}{\varepsilon-1}}
\end{aligned}
$$

where $\gamma$ is trade openness (the share of foreign goods in the consumption bundle), $\eta$ is the share of goods produced by ET firms, $C_{\mathrm{ET}, d}$ is the consumption of goods produced by domestic ET firms, $C_{\mathrm{IT}, d}$ the consumption of goods produced by domestic IT firms, $C_{\mathrm{ET}, m}$ the consumption of goods produced by foreign ET firms and $C_{\mathrm{IT}, m}$ the consumption of goods produced by foreign IT firms. The consumption price writes

$$
\begin{aligned}
& P_{c}=\left([(1-\gamma) \eta]\left(\tau^{c} P_{\mathrm{ET}}\right)^{1-\varepsilon}+\right. {[(1-\gamma)(1-\eta)] P_{\mathrm{IT}, d}^{1-\varepsilon} } \\
&\left.+[\gamma \eta]\left(\tau^{c} P_{\mathrm{ET}}^{*}\right)^{1-\varepsilon}+[\gamma(1-\eta)] P_{\mathrm{IT}, x}^{*}{ }^{1-\varepsilon}\right)^{\frac{1}{1-\varepsilon}}
\end{aligned}
$$

Investment only relies on ET-firms goods as it does not pay the consumption tax. The bundle writes

$$
I=\left((1-\gamma)^{\frac{1}{\varepsilon}} I_{d}^{\frac{\varepsilon-1}{\varepsilon}}+\gamma^{\frac{1}{\varepsilon}} I_{m}^{\frac{\varepsilon-1}{\varepsilon}}\right)^{\frac{\varepsilon}{\varepsilon-1}}
$$

The investment price writes

$$
P_{k}=\left((1-\gamma) P_{\mathrm{ET}}^{1-\varepsilon}+\gamma P_{\mathrm{ET}}^{* 1-\varepsilon}\right)^{\frac{1}{1-\varepsilon}}
$$

Public expenditures also relies on ET-firms goods. The bundle writes

$$
G=\left((1-\gamma)^{\frac{1}{\varepsilon}} G_{d}^{\frac{\varepsilon-1}{\varepsilon}}+\gamma^{\frac{1}{\varepsilon}} G_{m} \frac{\frac{\varepsilon-1}{\varepsilon}}{{ }^{\frac{\varepsilon}{\varepsilon-1}}}\right.
$$

The public expenditure price is given by

$$
P_{g}=\left((1-\gamma) P_{\mathrm{ET}}^{1-\varepsilon}+\gamma P_{\mathrm{ET}}^{* 1-\varepsilon}\right)^{\frac{1}{1-\varepsilon}}
$$


Demand functions Individual demands of Home households write (similar relations stand for the Foreign economy)

$$
\begin{aligned}
& C_{e t s, d}=(1-\gamma) \eta\left(\frac{\tau^{c} P_{\mathrm{ET}}}{P_{c}}\right)^{-\varepsilon} C \quad \text { (9) } \quad C_{i t s, d}=(1-\gamma)(1-\eta)\left(\frac{P_{\mathrm{IT}, d}}{P_{c}}\right)^{-\varepsilon} C \\
& C_{e t s, m}=\gamma \eta\left(\frac{\tau^{c} P_{\mathrm{ET}}^{*}}{P_{c}}\right)^{-\varepsilon} C \\
& I_{d}=(1-\gamma) \eta\left(\frac{P_{\mathrm{ET}}}{P_{k}}\right)^{-\varepsilon} I \\
& G_{d}=(1-\gamma) \eta\left(\frac{P_{\mathrm{ET}}}{P_{k}}\right)^{-\varepsilon} G \\
& C_{i t s, m}=\gamma(1-\eta)\left(\frac{P_{\mathrm{IT}, x}^{*}}{P_{c}}\right)^{-\varepsilon} C \\
& I_{m}=(1-\gamma) \eta\left(\frac{P_{\mathrm{ET}}^{*}}{P_{k}}\right)^{-\varepsilon} I \\
& G_{m}=(1-\gamma) \eta\left(\frac{P_{\mathrm{ET}}^{*}}{P_{k}}\right)^{-\varepsilon} G
\end{aligned}
$$

The demand for each sector writes

$$
\begin{aligned}
Y_{\mathrm{ET}} & =C_{\mathrm{ET}, d}+C_{\mathrm{ET}, m}^{*}+I_{d} \\
& +G_{d}+I_{m}^{*}+G_{m}^{*} \\
Y_{\mathrm{IT}, d} & =C_{\mathrm{IT}, d} \\
Y_{\mathrm{IT}, x} & =C_{\mathrm{IT}, m}^{*}
\end{aligned}
$$

$$
\begin{aligned}
Y_{\mathrm{ET}}^{*} & =C_{\mathrm{ET}, d}^{*}+C_{\mathrm{ET}, m}+I_{d}^{*} \\
& +G_{d}^{*}+I_{m}+G_{m} \\
Y_{\mathrm{IT}, d}^{*} & =C_{\mathrm{IT}, d}^{*} \\
Y_{\mathrm{IT}, x}^{*} & =C_{\mathrm{IT}, m}
\end{aligned}
$$

The trade balance of Home writes

$$
T B=\left[P_{\mathrm{ET}}\left(C_{\mathrm{ET}, m}^{*}+I_{m}^{*}\right)+P_{\mathrm{IT}, x} C_{\mathrm{IT}, m}^{*}\right]-\left[P_{\mathrm{ET}}^{*}\left(C_{\mathrm{ET}, m}+I_{m}\right)+P_{\mathrm{IT}, x}^{*} C_{\mathrm{IT}, m}\right]
$$

\section{LONG TERM IMPACT OF TAXATION IN AN ECONOMY WITH CAPITAL}

\subsection{The steady state}

The steady state analysis aims to evaluate the long run impact of tax reforms. The comparison between consumption tax and labor tax has been deeply discussed in the perspective of financing health and retirement. We refer to Gauthier (2006) and Fève et al. (2009) for the presentation of the main arguments. The underlying analysis of our model does not differ from the previous ones. Let $g$ the level of public spending (percentage of GDP at factor cost i.e. without taxes and subsidies). The level of investment is given by the modified golden rule $i=\frac{\varepsilon_{p}-1}{\varepsilon_{p}} \frac{\delta}{\delta+1 / \beta-1}(1-$ $\alpha)$. The remainder is consumption at equilibrium $(c=1-i-g)$. Table 1 shows the value-added decomposition.

As the savers in the economy are infinite-live households, the interest rate in the long run is driven by the exogenous time preference parameter $\beta$. As a result, at the steady state, the marginal rate of substitution only depends on technology, taxes and mark-ups.

$$
\operatorname{mrs}=\alpha A\left(\frac{1-\alpha}{\delta+1 / \beta-1}\right)^{\frac{1-\alpha}{\alpha}} \frac{\varepsilon_{p}-1}{\varepsilon_{p}} \frac{\varepsilon_{w}-1}{\varepsilon_{w}} \frac{\tau^{h}}{\tau^{f} \tau^{c}}
$$


Table 1 - Growth Domestic Product Decomposition

\begin{tabular}{llc}
\hline \multirow{2}{*}{ Labor income } & \multicolumn{1}{c}{ net compensation } & $(1-\alpha) \frac{\varepsilon_{p}-1}{\varepsilon_{p}} \frac{\tau^{h}}{\tau^{f}}$ \\
\cline { 2 - 3 } & social contributions & $(1-\alpha) \frac{\varepsilon_{p}-1}{\varepsilon_{p}}\left(1-\frac{\tau^{h}}{\tau^{f}}\right)$ \\
\hline \multirow{2}{*}{ Capital income } & profits & $\frac{\varepsilon_{p}-1}{\varepsilon_{p}} \alpha$ \\
\cline { 2 - 3 } & rents & $\frac{1}{\varepsilon_{p}}$ \\
\hline Taxes and subsidies & VAT receipts & $\left(\tau^{c}-1\right) c$ \\
\hline
\end{tabular}

In order to evaluate the effect of taxation in the model, the government budget constraint is the second pillar. $l s$ and $t r$ denote lump-sum taxes and transfers to households (it is relevant to distinguish the two flows as far as tax payers and subsidy recipients are not the same households) and $g$ the good purchased by the public sector, all in percentage of GDP. ${ }^{6}$ The budget constraint writes

$$
g+t r=l s+\left(\tau^{c}-1\right)(1-g-i)+(1-\alpha) \frac{\varepsilon_{p}-1}{\varepsilon_{p}}\left(1-\frac{\tau^{h}}{\tau^{f}}\right)
$$

To assess the effect of a fiscal reform, the choice of the variable that allows the budget constraint to be fulfill is crucial. For instance, when a government purchase is financed by a lump-sum tax, private consumption is reduced but the marginal rate of substitution is not affected (see Equation (24)). Given the specification of the utility, this drives up the labor supply. Now, assume a tax shift between labor and consumption and assume the government maintains the purchasing power of transfers, the level of debt and lump-sum taxes. ${ }^{7}$ Suppose also that labor supply is lower than the optimum (the government would like to increase the marginal rate of substitution), what is the right shifting direction? The government budget constraint implies

$$
\underbrace{\left[\tau^{c} c-t r\right]}_{\mathrm{A}} \frac{\mathrm{d} \tau^{c}}{\tau^{c}}=\underbrace{(1-\alpha) \frac{\varepsilon_{p}-1}{\varepsilon_{p}} \frac{\tau^{h}}{\tau^{f}}}_{\mathrm{B}}\left(\frac{\mathrm{d} \tau^{f}}{\tau^{f}}-\frac{\mathrm{d} \tau^{h}}{\tau^{h}}\right)
$$

As long as the non-subsidized consumption (term A) is larger than the net compensation of workers (term B), shifting tax from labor to consumption can be neutral on the government and increases labor supply (see Equation (24)).

An important assumption underlying this result is the absence of relation between the structure of taxes and the interest rate. Taxing consumption instead of labor means taxing the entire lifecycle instead of taxing the working years. In a more general context (overlapping-generation

\footnotetext{
${ }^{6}$ We assume no public debt.

${ }^{7}$ We compute transfers in terms of constant purchasing power in order to disentangle the effect on labor supply of having less taxation from the effect of having a better taxation.
} 
model), after shifting taxation from labor to consumption, households would probably save more during the working years and so the interest rate may decline, enforcing capital accumulation. If the economy is dynamically efficient, the gain to shift taxation from labor to consumption increases. In this context there is an additional redistributive issue, the so-called old wealth argument. When the reform is implemented, older households may claim a compensation for the lower purchasing power of their financial wealth (this compensation add to their claim concerning pay-as-you go pension system).

\subsection{Calibration}

Many parameters have to be calibrated or estimated in the model. Some are relevant for the steady state equilibrium: the share of capital in the production function $(1-\alpha)$, the share of rents (the mark-up) in the economy $1 / \varepsilon_{p}$, the discount factor $\beta$, the depreciation rate of capital $\delta$ and tax rates $\tau^{c}, \tau^{f}$ and $\tau^{h}$. Others are only relevant for the dynamic properties of the model: prices and wage rigidities, investment rigidities, the wage mark-up, labor supply elasticity, intertemporal elasticity of substitution. We will choose standard values for all these parameters (see Table 2).

Table 2 - Calibration

\begin{tabular}{lcc} 
Description & Name & Value \\
\hline Habit parameter & $b$ & 0.8 \\
Depreciation rate of capital & $\delta$ & 0.025 \\
\hline Share of government consumption in GDP & $g$ & 0.15 \\
Consumption tax rate & $\tau^{c}$ & 1.15 \\
worker social contribution rate & $\tau^{h}$ & 0.95 \\
firm social contribution rate & $\tau^{f}$ & 1.05 \\
\hline
\end{tabular}

The German economy weights 30\% of the Euro Area (1999-2005 average). The calibration of trade linkage between Germany and REA requires some statistical treatment. First, we compute the bilateral value added flows between Germany, the rest of the euro area and the rest of the world. Products' flows (imports and exports) and value added flows differ by large amount when one looks at bilateral flows among many countries and particularly for small open economies (processing trade). The methodology is developed in Appendix B and shows a 45\% overestimation for German $\leftrightarrow$ REA flows if the product-value added correction is ignored. In the second step, one has to choose which degree of openness to keep for Germany and the REA. As we look at spillovers from Germany to the rest of the Euro Area, we ignore trade with the rest of the world: German (value added) openness represents only $10 \%$ of GDP. 


\section{THE SHORT TERM IMPACT OF NATIONAL TAX REFORM}

\subsection{Transitory effect of fiscal shocks: an application to Germany}

After a 1 point increase in the consumption tax in Germany, monetary policy is almost unresponsive when $\eta=1$ and interest rate increases only weakly when $\eta=0$ due to the moderate share of Germany in euro area core-inflation. Area-wide inflation being stabilized, one sees opposite inflation dynamic in Germany (where prices go up) and in the REA (where prices go down). As a result, the real interest rate is too high in the REA and too low in Germany: in the short run, the REA shares the weight of the German's tax policy. The amplitude of those mechanisms depends on the share of ET firms in the economy: the higher $\eta$, the lower German's core-inflation and the more insulated the rest of the euro area from the tax policy (see Figure B.2, lines 1 and 2). A decrease of the labor tax rate that exactly compensates for the VAT increase (the effect on the fiscal balance is exactly the opposite), the effect on domestic and foreign variables are more benign in the short run and larger in the long run. ${ }^{8}$ The monetary policy reaction is higher when firms' social contributions are reduced (comparing to a reduction of the workers' social contributions) so the stimulation of the economy. But at the same time, price differential between the domestic and the foreign economy is higher, leading to a larger reallocation of demand to domestic firms. Despite an increase of consumption and investment, GDP is reduced in the rest of the euro area (see Figure B.2, lines 3 and 4).

We calibrate the model on the tax policy effectively implemented in Germany: a 3 points increase in VAT, based on $62 \%$ of consumption partially compensated by a decrease of 0.5 points of both workers' and firms' social contributions pre-announced one year before. Consumption is stimulated in the short run in Germany due to the real interest rate decrease and the permanent income effect. Household are expecting a one-shot increase in prices when the policy is implemented (1/4 of the mechanical effect in our calibration) and a higher consumption price inflation that will not be mitigated by the central bank. In the rest of the euro area, permanent income effect is positive (even small) but the real interest rate effect is negative: Consumption decreases by $0.15 \%$.

\subsection{The political economy of national tax reforms in a monetary union}

To go further in the analysis of tax reforms, we perform a welfare analysis. The impact of tax reforms on utility obviously depends on the total amount of inefficiencies in the economy (i.e. tax rates and mark-ups in the long run), but the relative impact when comparing two different reforms remains. Two main differences appear between the domestic economy and the rest of the monetary union. First, the weight of long run effects relative to short run ones is higher in

\footnotetext{
${ }^{8}$ For the sake of simplicity, the calibration assumes that the purchasing power of transfers to households are not maintained. Simulating a tax shift that preserves the purchasing power of transfers and is neutral for the government budget balance, one has to apply the ratio non-subsidies private consumption on overall private consumption to the labor tax simulation.
} 
the domestic economy. A deeper discussion on the nature of such spillovers in the euro area is not in the scope of this paper, but one may argue that those spillovers may be higher or lower than estimated here. Second, VAT reforms with a large share of IT firms or pre-announced VAT reforms see opposite short run effects on utility in the two regions. The negative impact of tax increase is lower in the short run in the country and higher in the rest of Euro area (see Figure 2).

Figure 2 - Households utility following a tax reform in Germany (\% of steady-state consumption)

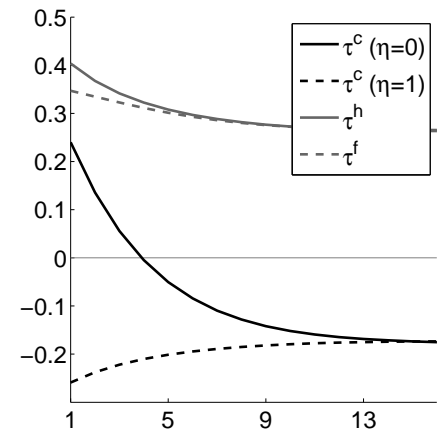

Germany

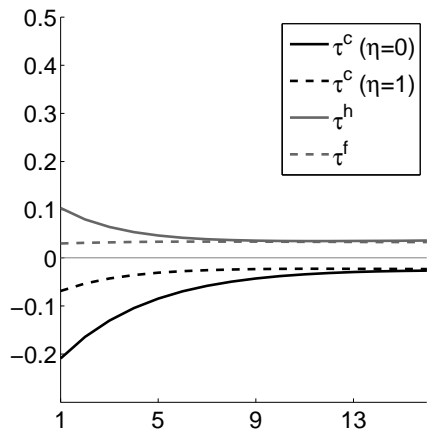

REA

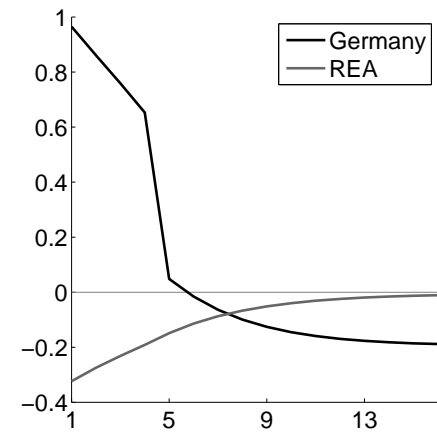

2007 reform

Table 3 reports the one year consumption variation which is equivalent to each policy in term of welfare. ${ }^{9}$ Spillovers of tax policies appear high if one takes into account the relative size of Germany and the rest of euro area. The sign of variation is always the same, but the relative spillovers are higher with a VAT rate increase and with a high share of IT firms. Due to the pre-announcement of the policy, the relative spillovers are high for the policy conducted by Germany in 2007.

Table 3 - Welfare effect of tax reforms

\begin{tabular}{lccccc}
\hline & $\tau^{c}$ & $\tau^{c}$ & $\tau^{h}$ & $\tau^{f}$ & 2007 \\
& $\eta=0$ & $\eta=1$ & \multicolumn{2}{c}{ equiv. VAT } & reform \\
\hline Germany & -0.60 & -0.65 & -0.99 & 0.98 & -0.47 \\
REA & -0.13 & -0.11 & -0.17 & -0.15 & -0.11 \\
relative & $\mathbf{0 . 2 2}$ & 0.17 & 0.17 & 0.16 & $\mathbf{0 . 2 3}$ \\
\hline
\end{tabular}

The welfare is measured by an equivalent variation of consumption during one year, in percentage

There is a major concern for countries to shift taxation from labor to consumption: for a constant total amount of taxation, the effect on GDP and welfare is positive (even moderate) in the long

\footnotetext{
${ }^{9} \mathrm{We}$ compute the difference of welfare at period 0 between the tax reform scenario (announced and/or implemented in period 1) and the "no tax reform" scenario.
} 
run. How this policy impacts the economy in the short run is uneasy to assess, but it seems that a monetary union enhances the short term positive impact of wage tax cuts and lowers the negative impact of consumption tax increase. At the same time, negative spillovers appear and the rest of the currency union inherits the short run burden of the policy.

\section{Conclusion}

We propose a framework to analyze the impact of tax shifting in a currency union. The main innovation of the paper is the introduction of heterogeneity among firms according to the way they set prices after a change in the consumption tax. Some of them set a price excluding-tax price and the remainder set an including-tax. This heterogeneity impacts on inflation dynamic

In the long run, tax shifting from labor to consumption may reduce the tax wedge if the nonsubsidized consumption is larger than the net of tax compensation of labor. In a currency union, a national consumption tax policy highly spills over the rest of the union whereas a wage tax policy is more neutral. As a consequence, the incitation scheme on governments to implement a tax shift from wage to consumption is modified at the expense of the rest of the currency union. 


\section{BIBLIOGRAPHY}

Adjemian, S., Cahn, C., Devulder, A., \& Maggiar, N. (2009). Variantes en Univers Incertain. Documents de Travail 236, Banque de France.

Boeters, S., Böhringer, C., Büttner, T., \& Kraus, M. (2006). Economic Effects of VAT Reform in Germany. ZEW Discussion Papers 06-30, ZEW - Zentrum für Europäische Wirtschaftsforschung / Center for European Economic Research. available at http://ideas.repec.org/p/zbw/zewdip/4614.html.

Chamley, C. (1986). Optimal taxation of capital income in general equilibrium with infinite lives. Econometrica, 54(3), 607-622.

Coenen, G., McAdam, P., \& Straub, R. (2007). Tax reform and labour-market performance in the euro area - a simulation-based analysis using the New Area-Wide Model. Working Paper Series 747, European Central Bank.

Coupet, M. \& Renne, J.-P. (2008). Réformes fiscales dans un modèle dsge france en économie ouverte. Économie et prévision, (183-184), 199-222.

Feenberg, D. R., Mitrusi, A. W., \& Poterba, J. M. (1997). Distributional effects of adopting a national retail sales tax. In M. Press (Ed.), Tax Policy and the Economy. Canbridge, Massachussetts: James M. Poterba.

Fève, P., Matheron, J., \& Sahuc, J.-G. (2009). Social VAT: Good or bad idea? Documents de travail, Banque de France.

Gauthier, S. (2006). Un exercice de TVA sociale. Working Papers 2006-07, Centre de Recherche en Economie et Statistique.

Henry, J., Hernandez de Cos, P., \& Momigliano, S. (2004). The short term impact of Government Budget on Prices, Evidence from Macroeconometrics Models. Working paper 396, European Central Bank.

Roeger, W. \& in't Veld, J. (2006). Shifting the burden of taxation from labour taxes to indirect taxes. Technical report. mimeo.

Smets, F. \& Wouters, R. (2003). An estimated dynamic stochastic general equilibrium model of the euro area. Journal of the European Economic Association, 1(5), 1123-1175. 


\section{APPENDIX}

\section{A. Price setting}

The marginal cost $M C_{t}$ of a domestic firm at period $t$ is independent of its price (constant return to scale) and is given by

$$
M C_{t}=\frac{1}{A}\left(\frac{r k_{t}}{\alpha}\right)^{\alpha}\left(\frac{\tau_{t}^{f} W_{t}}{1-\alpha}\right)^{1-\alpha}
$$

\section{A.1. Price setting in the excluding of tax sector}

Firms that reset their price in period $t$ in the ET sector will choose the price $\tilde{P}_{\mathrm{ET}, t}$ that maximizes the current market value of the profits generated while that price remains effective:

$$
\max _{\tilde{P}_{\mathrm{ET}, t}} \mathbf{E}_{t}\left\{\sum_{k=0}^{\infty} v_{p}^{k} \mathscr{F}_{t}^{t+k}\left[\tilde{P}_{\mathrm{ET}, t}-M C_{t+k}\right]\left(\frac{\tilde{P}_{\mathrm{ET}, t}}{P_{\mathrm{ET}, t+k}}\right)^{-\varepsilon_{p}} Y_{\mathrm{ET}, t+k}\right\} .
$$

The first order condition leads to the following optimal price setting

$$
\tilde{P}_{\mathrm{ET}, t}=\frac{\varepsilon_{p}}{\varepsilon_{p}-1} \frac{\mathbf{E}_{t}\left\{\sum_{k=0}^{\infty} v_{p}^{k} \mathscr{F}_{t}^{t+k}\left(\frac{\tilde{\mathrm{E}}_{\mathrm{ET}, t}}{P_{\mathrm{ET}, t+k}}\right)^{-\varepsilon_{p}} Y_{\mathrm{ET}, t+k} M C_{t+k}\right\}}{\mathbf{E}_{t}\left\{\sum_{k=0}^{\infty} v_{p}^{k} \mathscr{F}_{t}^{t+k}\left(\frac{\tilde{P}_{\mathrm{ET}, t}}{P_{\mathrm{ET}, t+k}}\right)^{1-\varepsilon_{p}} Y_{\mathrm{ET}, t+k} P_{\mathrm{ET}, t+k}\right\}} P_{\mathrm{ET}, t} .
$$

\section{A.2. Price setting in the including tax sector for the domestic market}

Firms that reset their price in period $t$ in the IT sector for the domestic market will choose the price $\tilde{P}_{\mathrm{IT}, d, t}$ that maximizes the current market value of the profits generated while that price remains effective:

$$
\max _{\tilde{P}_{\mathrm{IT}, x, t}} \mathbf{E}_{t}\left\{\sum_{k=0}^{\infty} v_{p}^{k} \mathbf{E}_{t} \mathscr{F}_{t}^{t+k}\left[\frac{\tilde{P}_{\mathrm{IT}, d, t}}{\tau_{t+k}^{c}}-M C_{t+k}\right]\left(\frac{\tilde{P}_{\mathrm{IT}, d, t}}{P_{\mathrm{IT}, d, t+k}}\right)^{-\varepsilon_{p}} Y_{\mathrm{IT}, d, t+k}\right\} .
$$

The first order condition leads to the following optimal price setting

$$
\tilde{P}_{\mathrm{IT}, d, t}=\frac{\varepsilon_{p}}{\varepsilon_{p}-1} \frac{\mathbf{E}_{t}\left\{\sum_{k=0}^{\infty} v_{p}^{k} \mathscr{F}_{t}^{t+k}\left(\frac{\tilde{P}_{\mathrm{IT}, d, t}}{P_{\mathrm{IT}, d, t+k}}\right)^{-\varepsilon_{p}} Y_{\mathrm{IT}, d, t+k} M C_{t+k}\right\}}{\left.\mathbf{E}_{k=0}^{\infty} v_{p}^{k} \mathscr{F}_{t}^{t+k}\left(\frac{\tilde{P}_{\mathrm{IT}, d, t}}{P_{\mathrm{IT}, d, t+k}}\right)^{1-\varepsilon_{p}} Y_{\mathrm{IT}, d, t+k} P_{\mathrm{IT}, d, t+k} / \tau_{t+k}^{c}\right\}} P_{\mathrm{IT}, d, t} .
$$

\section{A.3. Price setting in the including tax sector for the export market}

Firms that reset their price in period $t$ in the IT sector for the export market will choose the price $\tilde{P}_{\mathrm{IT}, x, t}$ that maximizes the current market value of the profits generated while that price remains effective:

$$
\max _{\tilde{P}_{\mathrm{IT}, x, t}} \mathbf{E}_{t}\left\{\sum_{k=0}^{\infty} v_{p}^{k} \mathscr{F}_{t}^{t+k}\left[\frac{\tilde{P}_{\mathrm{IT}, x, t}}{\tau^{c *}{ }_{t+k}^{*}}-M C_{t+k}\right]\left(\frac{\tilde{P}_{\mathrm{IT}, x, t}}{P_{\mathrm{IT}, x, t+k}}\right)^{-\varepsilon_{p}} Y_{\mathrm{IT}, x, t+k}\right\} .
$$


The first order condition leads to the following optimal price setting

$$
\tilde{P}_{\mathrm{IT}, x, t}=\frac{\varepsilon_{p}}{\varepsilon_{p}-1} \frac{\mathbf{E}_{t}\left\{\sum_{k=0}^{\infty} v_{p}^{k} \mathscr{F}_{t}^{t+k}\left(\frac{\tilde{P}_{\mathrm{IT}, x, t}}{P_{\mathrm{IT}, x, t+k}}\right)^{-\varepsilon_{p}} Y_{\mathrm{IT}, x, t+k} M C_{t+k}\right\}}{\left.\sum_{k=0}^{\infty} \nu_{p}^{k} \mathscr{F}_{t}^{t+k}\left(\frac{\tilde{I}_{\mathrm{IT}, x, t}}{P_{\mathrm{IT}, x, t+k}}\right)^{1-\varepsilon_{p}} Y_{\mathrm{IT}, x, t+k} P_{\mathrm{IT}, x, t+k} / \tau_{t+k}^{c *}\right\}} P_{\mathrm{IT}, x, t} .
$$

\section{A.4. Wage setting}

The first order condition on wage setting writes

$$
\mathbf{E}_{t}\left\{\sum_{k=0}^{\infty} v_{w}^{k} \beta^{k}\left(\frac{\tau_{t+k}^{h} \tilde{W}_{t}}{P_{c, t+k}}\left(C_{t+k}(j)-\bar{C}_{t+k}\right)^{-\sigma}-\left(\frac{\tilde{W}_{t}}{W_{t+k}}\right)^{-\phi \varepsilon_{w}} N_{t+k}^{\phi}\right)\left(\frac{\tilde{W}_{t}}{W_{t+k}}\right)^{\varepsilon_{w}} N_{t+k}\right\}=0
$$

\section{B. Trade model calibration}

The model considers value added trade while international statistics data records goods and service trade. In international statistics, a British airlines company buying an Airbus plane that has been partly produced in Germany will be recorded as two flows: an export from Germany to France and an export from France to United Kingdom. Value added flows accounting is different: one should consider an export from Germany to UK and an export from France to UK; those two flows increase UK capital stock. ${ }^{10}$ Value added flows are smaller and do not share the same geographic pattern than goods flows.

In order to evaluate value added flows from international statistics, we split goods and services used in country $i$ in three purposes: final domestic demand $A_{i}$, exports $X_{i}$ and intermediate consumption $I C_{i}$. Let $Y_{i}$ the domestic production (including intermediate consumption) and $M_{i}$ imports (as in international statistics). One has

$$
Y_{i}+M_{i}=A_{i}+X_{i}+I C_{i}
$$

Assumption 1: We assume a complementary factors technology. ${ }^{11}$ Those factors are (i) imported intermediate consumption, (ii) domestic intermediate consumption and (iii) production factors (capital and labor, which amount is equal to the value added)

$$
Y_{i}=\min \left(\frac{M_{i}^{i c}}{1-\varepsilon_{i}-\gamma_{i}}, \frac{Y_{i}^{i c}}{\varepsilon_{i}}, \frac{F_{i}}{\gamma_{i}}\right) .
$$

$M_{i}{ }^{i c}$ represents the amount of imports used for intermediary consumption, $Y_{i}{ }^{c i}$ is the domestic production of intermediate goods, and $F_{i}$ is value added. One has

$$
Y_{i}=\underbrace{M_{i}^{i c}+Y_{i}^{i c}}_{\text {int. consump. }}+F_{i}
$$

Let $\alpha$ and $\beta$ the share of imports in final domestic demand and exports (respectively). For a given level of final domestic demand and exports, production and imports are given by

$$
\begin{gathered}
Y_{i}=\left(1-\alpha_{i}\right) A_{i}+\left(1-\beta_{i}\right) X_{i}+\varepsilon_{i} Y_{i} \\
M_{i}=\alpha_{i} A_{i}+\beta_{i} X_{i}+\left(1-\varepsilon_{i}-\gamma_{i}\right) Y_{i}
\end{gathered}
$$

\footnotetext{
${ }^{10}$ This is the accurate accounting, even if the plane will carry Chinese passengers on the Shanghai-Tokyo line.

${ }^{11}$ Which is equivalent to assume constant returns to scale and constant relative prices.
} 
Assumption 2: The share of country $j$ in imports of country $i$ is independent of the origin of the demand (intermediate consumption, final domestic demand, exports).

Let $\theta_{i j}$ this share (one has $\sum_{j \neq i} \theta_{i j}=1$ ). We can now evaluate bilateral goods flows and total exports of each area

$$
\begin{gathered}
M_{i j}=\theta_{i j}\left[\alpha_{i} A_{i}+\beta_{i} X_{i}+\left(1-\varepsilon_{i}-\gamma_{i}\right) Y_{i}\right] \\
X_{i}=\sum_{j \neq i} M_{j i}=\sum_{j \neq i} \theta_{j i}\left[\alpha_{j} A_{j}+\beta_{j} X_{j}+\left(1-\varepsilon_{j}-\gamma_{j}\right) Y_{j}\right]
\end{gathered}
$$

One can reorder terms

$$
X_{i}-\sum_{j \neq i} \theta_{j i} \beta_{j} X_{j}=\sum_{j \neq i} \theta_{j i}\left[\alpha_{j} A_{j}+\left(1-\varepsilon_{j}-\gamma_{j}\right) Y_{j}\right]
$$

We now have the three following equations that allow to evaluate value added flows

$$
\begin{array}{rlr}
\left(I-\Theta^{\prime} D_{\beta}\right) X & =\Theta^{\prime}\left[D_{\alpha} A+\left(I-D_{\varepsilon}-D_{\gamma}\right) Y\right] & \text { (exports) } \\
\left(I-D_{\varepsilon}\right) Y & =\left(I-D_{\alpha}\right) A+\left(I-D_{\beta}\right) X & \text { (demand) } \\
F & =D_{\gamma} Y & \text { (supply) }
\end{array}
$$

We develop the calculus (elimination of $X$ and $Y$ ) in the case where final domestic demand and exports do not command any imports $(\alpha=\beta=0)$

\begin{tabular}{|c|c|c|c|c|c|c|c|}
\hline & \multicolumn{3}{|c|}{ to } & \multicolumn{3}{|c|}{ to } \\
\hline & & Ger & REA & RoW & Ger & REA & RoW \\
\hline \multirow{3}{*}{ from } & Ger & $0 \%$ & $0,80 \%$ & $1,10 \%$ & $0 \%$ & $0,57 \%$ & $0,94 \%$ \\
\hline & REA & $0,65 \%$ & $0 \%$ & $2,00 \%$ & $0,44 \%$ & $0 \%$ & $1,72 \%$ \\
\hline & RoW & $0,86 \%$ & $1,94 \%$ & $0 \%$ & $0,69 \%$ & $1,66 \%$ & $0 \%$ \\
\hline
\end{tabular}

$$
\begin{gathered}
{\left[I-D_{\varepsilon}-\Theta^{\prime}\left(I-D_{\varepsilon}-D_{\gamma}\right)\right] D_{\gamma}{ }^{-1} F=A \quad \text { or } \quad F=\Omega A} \\
\underbrace{F_{i}}_{\text {VA produced in } i}=\underbrace{w_{i i} A_{i}}_{\text {VA consumed in } i}+\underbrace{\sum_{j \neq i} \omega_{i j} A_{j}}_{\text {VA exported }}
\end{gathered}
$$

Exports of value added from country $i$ to country $j$ are equal to $\omega_{i j} A_{j}$. Bilateral trade data in percentage of world output for Germany, the rest of the Euro Area and the rest of the world is given for product and value added in the following table (see Table B.1).

Table B.1 - World trade, 1999-2004 average, \% of world GDP

Products flows Value added flows

Sources : GTAP, author's calculation 
Figure B.1 - Domestic and external effect of tax policies in Germany (in \%)

\section{Germany}
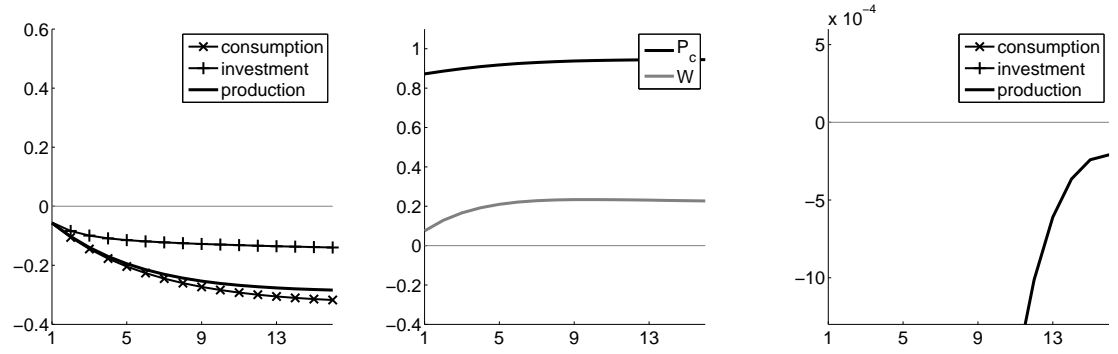

1 point VAT increase, $\eta=1$
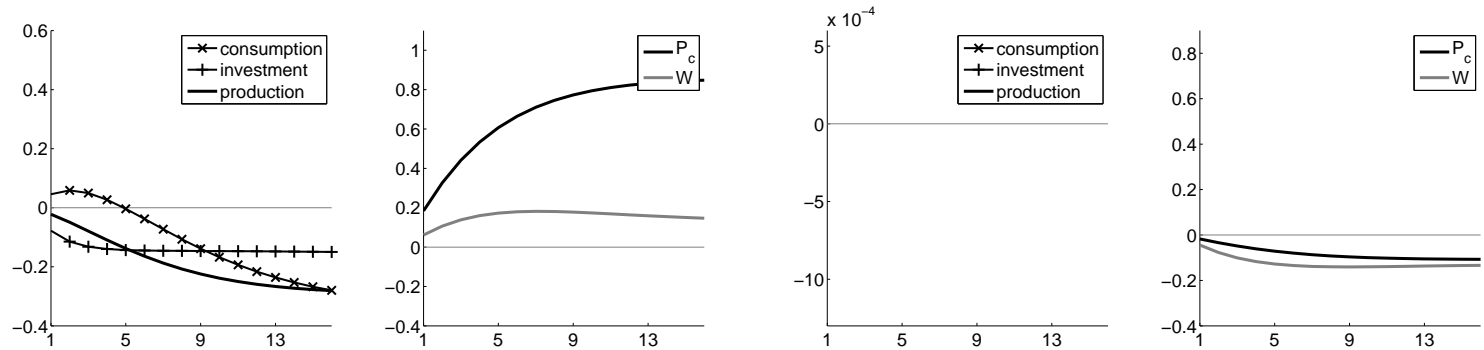

1 point VAT increase, $\eta=0$
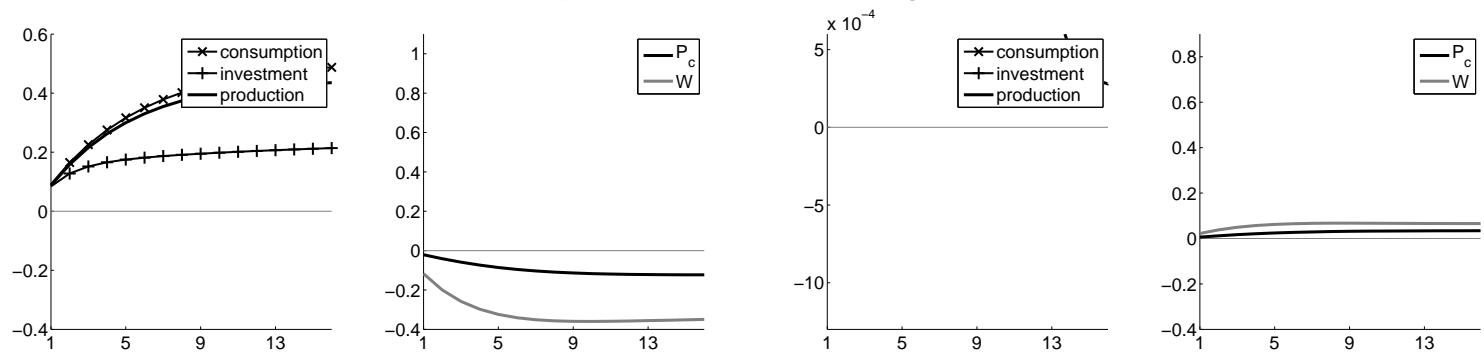

Workers' social contribution decrease (compensate VAT)
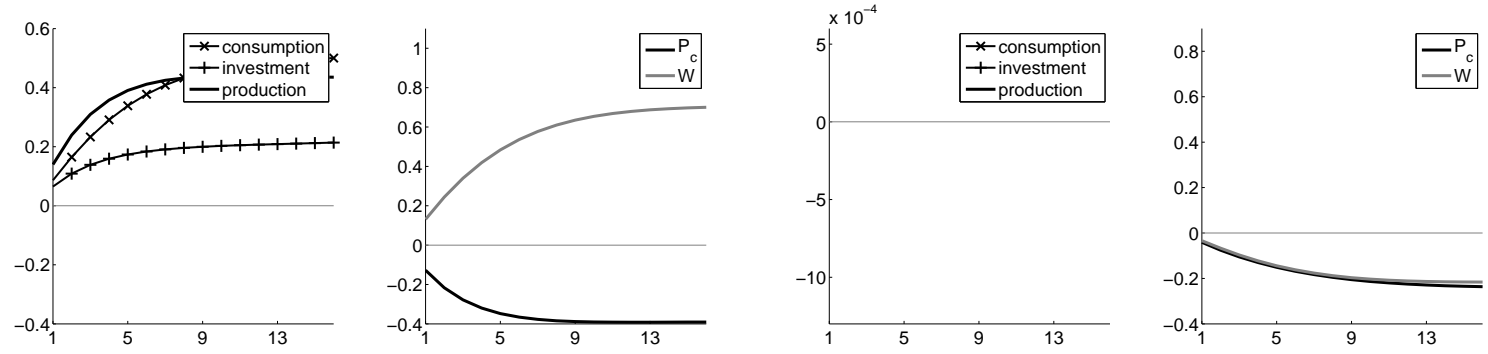

Firms' social contribution decrease (compensate VAT) 


\section{LIST OF WORKING PAPERS RELEASED BY CEPII}

An Exhaustive list is available on the website: \|www.cepii.fr.

No

Title

2012-22 The Unequal Effects of Financial Development on Firms’ Growth in India

2012-21 Pegging Emerging Currencies in the Face of Dollar Swings

2012-20 On the Links between Stock and Comodity Markets' Volatility

2012-19 European Export Performance, Angela Cheptea

2012-18 The Few Leading the Many: Foreign Affiliates and Business Cycle Comovement

2012-17 Native Language, Spoken Language, Translation and Trade

2012-16 Assessing the Price-Raising Effect of Non-Tariff Measures in Africa

2012-15 International Migration and Trade Agreements: the New Role of PTAs

2012-14 Scanning the Ups and Downs of China's Trade Imbalances

2012-13 Revisiting the Theory of Optimum Currency Areas: Is the CFA Franc Zone Sustainable?

2012-12 Macroeconomic Transmission of Eurozone Shocks to Emerging Economies
Authors

M. Bas \& A. Berthou

V. Coudert, C. Couharde \& V. Mignon

A. Creti, M. Joëts \& V. Mignon

A. Cheptea, L. Fontagné \& S. Zignago

J. Kleinert, J. Martin \& F. Toubal

J. Melitz \& F. Toubal

O.Cadot \& J.Gourdon

G. Orefice

F. Lemoine \& D. Ünal C. Couharde, I. Coulibaly, D. Guerreiro \& V. Mignon

B. Erten 
2012-11 The fiscal Impact of Immigration in France: a

X. Chojnicki

Generational Accounting Approach

2012-10 MAcMap-HS6 2007, an Exhaustive and Consistent Measure of Applied Protection in 2007

2012-09 Regional Integration and Natural Resources: Who Benefits? Evidence from MENA

2012-08 A Foreign Direct Investment Database for Global CGE Models

2012-07 On Currency Misalignments within the Euro Area

2012-06 How Frequently Firms Export? Evidence from France

2012-05 Fiscal Sustainability in the Presence of Systemic Banks: the Case of EU Countries

H. Guimbard, S. Jean, M. Mimouni \& X. Pichot

C. Carrère, J. Gourdon \& M. Olarreaga

C. Gouël, H. Guimbard \& D. Laborde

V. Coudert, C. Couharde \& V. Mignon

G. Békés, L. Fontagné, B. Muraközy \& V. Vicard

A. Bénassy-Quéré \& G. Roussellet

J. Martin \& I. Méjean across Firms and the Quality Content of Exports

2012-03 The Great Shift: Macroeconomic Projections for the World Economy at the 2050 Horizon

J. Fouré, A. Bénassy-Quéré \& L. Fontagné

2012-02 The Discriminatory Effect of Domestic Regulations on International Services Trade: Evidence from FirmLevel Data

2012-01 Optimal food price stabilization in a small open developing country

2011-33 Export Dynamics and Sales at Home

N. Berman, A. Berthou

\& J. Héricourt

2011-32 Entry on Difficult Export Markets by Chinese F. Mayneris \& S. Poncet Domestic Firms: The Role of Foreign Export Spillovers 
2011-31 French Firms at the Conquest of Asian Markets: The

F. Mayneris \& S. Poncet Role of Export Spillovers

2011-30 Environmental Policy and Trade Performance: Evidence from China

2011-29 Immigration, Unemployment and GDP in the Host Country: Bootstrap Panel Granger Causality Analysis on OECD Countries

2011-28 Index Trading and Agricultural Commodity Prices: A Panel Granger Causality Analysis

G. Capelle-Blancard \& D. Coulibaly

B. Carton

2011-27 The Impossible Trinity Revised: An Application to China

2011-26 Isolating the Network Effect of Immigrants on Trade

2011-25 Notes on CEPII's Distances Measures: The GeoDist Database

2011-24 Estimations of Tariff Equivalents for the Services Sectors

M. Aleksynska \& G. Peri

T. Mayer \& S. Zignago

L. Fontagné, A. Guillin \& C. Mitaritonna

2011-23 Economic Impact of Potential Outcome of the DDA

Y. Decreux \& L. Fontagné

2011-22 More Bankers, more Growth? Evidence from OECD Countries

G. Capelle-Blancard \& C. Labonne

2011-21 EMU, EU, Market Integration and Consumption Smoothing

2011-20 Real Time Data and Fiscal Policy Analysis

J. Cimadomo

2011-19 On the inclusion of the Chinese renminbi in the SDR basket
A. Bénassy-Quéré \& D. Capelle

2011-18 Unilateral trade reform, Market Access and Foreign Competition: the Patterns of Multi-Product Exporters

M. Bas \& P. Bombarda 
2011-17 The "Forward Premium Puzzle" and the Sovereign Default Risk

2011-16 Occupation-Education Mismatch of Immigrant Workers in Europe: Context and Policies

2011-15 Does Importing More Inputs Raise Exports? Firm Level Evidence from France

2011-14 Joint Estimates of Automatic and Discretionary Fiscal Policy: the OECD 1981-2003

2011-13 Immigration, vieillissement démographique et financement de la protection sociale : une évaluation par l'équilibre général calculable appliqué à la France

2011-12 The Performance of Socially Responsible Funds: Does the Screening Process Matter?

2011-11 Market Size, Competition, and the Product Mix of Exporters

2011-10 The Trade Unit Values Database

2011-09 Carbon Price Drivers: Phase I versus Phase II Equilibrium

2011-08 Rebalancing Growth in China: An International Perspective

2011-07 Economic Integration in the EuroMed: Current Status and Review of Studies

2011-06 The Decision to Import Capital Goods in India: Firms' Financial Factors Matter

2011-05 FDI from the South: the Role of Institutional Distance and Natural Resources
V. Coudert \& V. Mignon

M. Aleksynska \& A. Tritah

M. Bas \& V. Strauss-Kahn

J. Darby \& J. Mélitz

X. Chojnicki \& L. Ragot

G. Capelle-Blancard \& S. Monjon

T. Mayer, M. Melitz \& G. Ottaviano

A. Berthou \& C. Emlinger

A. Creti, P.-A. Jouvet \& V. Mignon

A. Bénassy-Quéré, B. Carton \& L. Gauvin

J. Jarreau

A. Berthou \& M. Bas

M. Aleksynska \& O. Havrylchyk 
No

Title

Authors

2011-04b What International Monetary System for a fastchanging World Economy?

A. Bénassy-Quéré \& J. Pisani-Ferry

2011-04a Quel système monétaire international pour une économie mondiale en mutation rapide?

A. Bénassy-Quéré \& J. Pisani-Ferry

2011-03 China's Foreign Trade in the Perspective of a more Balanced Economic Growth

G. Gaulier, F. Lemoine \& D. Ünal

2011-02 The Interactions between the Credit Default Swap and the Bond Markets in Financial Turmoil

2011-01 Comparative Advantage and Within-Industry Firms M. Crozet \& F. Trionfetti Performance 
Organisme public d'étude et de recherche en économie internationale, le CEPII est placé auprès du Centre d'Analyse Stratégique. Son programme de travail est fixé par un conseil composé de responsables de l'administration et de personnalités issues des entreprises, des organisations syndicales et de l’Université.

Les documents de travail du CEPII mettent à disposition du public professionnel des travaux effectués au CEPII, dans leur phase d'élaboration et de discussion avant publication définitive. Les documents de travail sont publiés sous la responsabilité de la direction du CEPII et n'engagent ni le conseil du Centre, ni le Centre d'Analyse Stratégique. Les opinions qui y sont exprimées sont celles des auteurs.

Les documents de travail du CEPII sont disponibles sur le site : http//www.cepii.fr. 